\title{
CULTURAL HERITAGE POLICY (1917-1922): LEGISLATION ON PROTECTION OF ARTWORKS AND ANTIQUITIES FROM RUSSIAN EMPIRE'S COLLAPSE TO THE USSR
}

\section{Rinata Kazak ${ }^{1}$}

DOI: https://doi.org/10.30525/978-9934-588-15-0-81

Abstract. Modern issues of the cultural heritage protection, as well as the ensuring legitimate turnover of artworks and antiquities, necessitate recourse to the historical and legal experience. The aim of the research is to make a holistic review of the basic regulations of post-revolutionary Russia, from Russian Empire's collapse in 1917 to the new state creation the Soviet Union in 1922, in the field of antiquities and artworks, in order to identify the fundamental direction of cultural property protection in Eastern Europe. This paper provides the comprehensive overview of all normative acts in the field of the cultural heritage in the designated chronological period (namely, twelve acts). Using the chronological method of historical and legal research the material of the article is presented in order of adoption at the legislative level. Legislative overview makes it possible to highlight notable features of the designated period as 1) the priority of the cultural property transfer to their historic homeland (namely the acts concerning the return of cultural inheritance to Ukraine, Poland and Lithuania); 2) creation of the accounting base, which is regarded as a balanced approach with the expectation of the further development; 3) multilevel structure of state bodies for the protection and preservation of art and antiquities at national and local levels (ensuring the modern principle of subsidiarity); 4) consolidation of the ethical value of art and antiquities at the legislative level. The security and ethical functions can be distinguished qua two principal vectors of the post-revolutionary activity on the protection of artworks and antiquities. Coincidently, certain negative factors and the dual nature of the above-mentioned goals of the then government were singled out.

\footnotetext{
${ }^{1} \mathrm{PhD}$, Assistant Professor,

Yaroslav Mudryi National Law University, Ukraine
} 


\section{Introduction}

Cultural objects as artworks and antiquities have multilevel significance and crucial historical, cultural and financial value, representing the huge concern on effective legal coverage of its protection and trade. Consequently, the legislative regulation of the protection and circulation of art and antiques is a constituent element of the preservation of cultural heritage at the state level. Modern issues of protection of cultural property, ensuring their legal turnover, as well as the creation of a state and world accounting bases for such items, necessitate the recourse to the historical and legal experience of this field. A number of the internal and external factors cause the need to develop best practices for the conservation and protection of antiquities. The multi-ethnic population of Europe, unstoppable process of migration, the diversity of cultures and religions, the current unstable situation in Eastern Europe, the precariousness of territorial borders and plenty of military conflicts give rise to the urgent need to take into account the development of the cultural heritage protection in order to create effective legislative foundations. The recent centenary of the October Revolution can serve as an occasion for the reminiscence for the social, economical and political changes of that time. The core point of the study is to explore the main vectors of the post-revolutionary government policy in the field the cultural heritage protection on the territory of the former Russian Empire, from its collapse in 1917 to creating a new state - the Soviet Union in 1922. This chronological framework was chosen in order to consider the formation of the basis on which the legislation of the USSR was built for the next 70 years and left a large imprint in the post-Soviet republics.

\section{Sources and instruments of cultural heritage policy research}

Currently, all over the world there were adopted legal acts that ensure protection of work of art and antiquities, as for Europe it is necessary to mention two key EU acts (Council Regulation (EEC) No 3911/92 of 9 December 1992 on the export of cultural goods and Council Directive 93/7/EEC of 15 March 1993 on the return of cultural objects unlawfully removed from the territory of a Member State), which scientists consider as a «double safeguarde» (Hoffmann, 2006) [1]. Furthermore, in May, 21, 2014 the EU Council adopted the conclusions [2] on cultural heritage as a strategic resource for a sustainable Europe called for «the development 
of a strategic approach to cultural heritage» defining the specific role that cultural heritage plays for "smart, sustainable and inclusive growth" [2] as it has influence along with social and economic impact and contributes to environmental sustainability. Scientists agree that arising interest of world communities in the cultural heritage issues is closely linked to the process of globalization (Charles O. Lerche III, 1998 [3]; Petkova, 2005 [4]). Some scholars supposed that the illicit antiquities trade represents "the darker side" of globalization (Fisman \&Wei, 2007) [5], thus it forces to consider the beginning of the 20th century, and recent centenary of the Russian Revolution, as a core issue for the creation of a modern system of cultural heritage protection, because any revolutionary action involves theft, looting, vandalism and other illegal actions on the one hand and brought the society to the modern level of globalization, on the other. We surely agree that the advantage of legal history as compared to, jurisprudence, is the flexibility it offers scholars to see the many faces of law (Fisk \& Gordon, 2011) [6]. The 1917 was marked by a turning point in the life of Eastern Europe, and along with hundred-year geo-political events there were changes at the legal level. Therefore, due to the methodology of the history of law, it becomes possible to consider the diachronic formation and development of this field.

The aim of the article is a review of the basic regulations of post-revolutionary Russia on the protection of cultural heritage in the complex (changeable nature) during the emergence of a new government of the territory of the former Russian Empire, in the period from its collapse in 1917 to creation a new state of the USSR in 1922. The main scope is to identify the main features of shaping and development of the modern idea of the protection of the cultural property in Eastern Europe and the Soviet republics.

Using the chronological method of historical and legal research, the material of the article will be presented in the order of adoption at the legislative level. Historical method is the main element that is determined by the fact that this field was continually developed from the beginning of the $20^{\text {th }}$ century till nowadays: the fall of the Russian Empire to the USSR creation, its collapse in 1991, the transformation of three post-Soviet states (Estonia, Latvia and Lithuania) into the EU member-states, etc. causing sweeping changes in the legislation. Consequently, background of the modern challenges would be appropriate to figure out. 
The main focus of the investigation is given to the primary sources, as the general cognitive tool. The paper provides the comprehensive overview of all normative acts in the field of the cultural heritage in the designated chronological period (namely, there were adopted twelve acts as Resolutions, Communications (Reports) and Decrees of the Council of People's Commissars, the People's Commissariat of Education, the Higher Council of National Economy for the Import Department).

Considering the topic is not focused on the general issue, but has a retrospective historical nature, therefore the secondary sources are not extensive and have a lack of the firm focus on this particular historical period. Due to the fact that cultural issues are very 'personal' matters of certain ethnic groups, nations and states, many scientists chose particular countries as a research subject. Identifying existing literature, it can be mentioned studies on legal matters concerning antiques in different European countries without considering historical aspects of law in this field (i.e. Cyprus (Jansen, 2005) [7], Estonia (Alatalu, 2013) [8], Slovenia and Balkan region (Prezelj, 2005) [9] (Petkova, 2005) [10], Switzerland (Weber, 2006 [11], Kunitz, 2001 [12], Renold, 2010 [13]), Spain (Amineddoleh, 2012) [14]. Furthermore, existing literature covers too broad scope of the study (i.e. referring "international heritage law" even without distinguishing of cultural and natural heritage separately (Lixinski, 2012 [15]), or aims to analyse too specific non-legal aspects as, for example, role of museums in the trade of black market cultural heritage (Amineddoleh, 2013 [16]).

As is evident from the foregoing, very few has been written specifically on antiquities turnover in historical and legal aspects without considering other general matters. The absence of research from the standpoint of legal history that could allow to determine the historical peculiarities of the art and antiquities circulation corroborate the relevance of this particular scientific survey.

\section{Internationational aspect of cultural heritage protection in post-revolutionary Russia}

The basis for the optimal provision of a socio-cultural policy as one of the three key elements of sustainable development (economy, ecology and culture) is the effective protection of cultural heritage, both of each individual state and nation, and of the world community as a whole. Along with the 
material value, the objects of art and antiques are characterized by a number of specific features - 1) cultural and ethical value, which can sometimes not be established in monetary terms; 2) the need for certain common databases with information about the object; 3 ) historical value for a particular nation / region / country.

In accordance with the characteristics of these objects it is required by the legislator a legal consolidation of the order of purchase/sale, import/ export, registration and international cooperation in matters of protection of cultural property. The issues of legal securing of the protection and circulation of works of art and antiques (antiquities) have several different aspects, to which it can be related: a) providing the information - registration and accounting of such items, b) legal regulation of its turnover - import / export, trade, c) international aspect - the need for the return of cultural property to their historic homeland. These multifaceted aspects and will be considered in this historical and legal study.

It is remarkable to note that the post-revolutionary Russia has gone through the path of modern social justice, having designated the "international aspect" in the very first regulatory document of this sphere. Namely, the return of objects to their historical homeland became chronologically the first action enshrined in normative documents in the field of the protection of cultural property. But it should also be noted that after the revolution the new bolshevik's government desiderate to finally consolidate its positions in the geo-political space, which is why the first acts were adopted interaction with neighboring states. The author of the study sees this as not so much an ethical component or a real concern for the preservation of cultural values, as it may seem at first glance, but a purely political aspect. The post-revolutionary government acted by "political coaxing".

More specifically, the first act of this period should be designated as the Decree of the People's Commissariat for the Education of the RSFSR of December 1, 1917 "On the transfer of trophies to the Ukrainian people" [17] according to which the Central Executive Committee of Soviets adopted a resolution on the transfer to the Ukrainian people of military trophies and historical relics taken by Russians from Ukrainians.

The next act of a similar nature was the report of the Council of People's Commissars on December 9, 1917, "On the issue of the regional Muslim congress of the Holy Quran of Osman" [18] which decided to immediately 
extradite the Muslim Muslim Congress to the possession of the Muslims of this religious relic at that time in the State Public Library, "In fulfillment of the aspirations of all Russian Muslims".

The legislative consolidation of the international character in the matters of preservation of the cultural property was further reflected at the beginning of 1918, when Soviet Russia adopted two acts according to which were regulated 1) the protection and return of artworks and antiquities belonging to the Polish people [19] and 2) the return of a cultural objects evacueted from Poland and had an artistic, scientific and historical heritage to Polish people [20]. The necessity of the protection and return was justified by the fact that, in the government's opinion, in some cities and country estates of the Russian Republic (namely, in the western and north-western provinces), people of Polish nationality had items of exceptional artistic or historical value for the Polish people.

In this regard, the Council of People's Commissars ordered the number of measures, and has developed a comprehensive legal framework for the return of these items to the 'whole Polish nation' in complete safety. According to par. 1 of this decree antiques and art, libraries, archives, paintings and general museum objects taken as the national property of the Polish people, under the protection of the workers 'and Peasants' Government, represented by Commissioner for Polish affairs and the "Society for the Preservation of Antiquities" before handing them to the Polish national museums.

When accepting under the protection of the above objects, an act was drawn up (and the act on the voluntary transfer of objects in Polish manors to Polish museums was signed by the owner of the manor himself or by his authorized representative). Such a document was drawn up in two copies, which were stored in accordance with paragraph 2:1) in the Polish commissariat under the Council of People's Commissars, 2) in the Petrograd department of the Polish Society for the Preservation of Antiquities, official representative of Polish artistic and historical societies in Russia. In addition to such acts, an exact inventory of the transferred items was compiled in 4 copies, one of which remained with the owner, the other in the commissariat for Polish affairs, the third in the regional commissariat for the protection of historical monuments or the office of the nearest executive body of the Union of the Servicemen of the Poles, the fourth on the board "Society for the Preservation of Antiquities" in Petrograd (paragraph 3). 
To implement this mechanism (compilation of acts and inventories, control over the observance of the decree on the ground), the Polish Commissariat appointed special district commissars with the powers of the Commissars of the Workers' and Peasants' Government (paragraph 4) who worked in contact with local authorities (par. 5).

A half a year later, a second normative act concerning the return to the Polish working people of the cultural, artistic, scientific and historical heritage evacuated from Poland was adopted (Resolution of the People's Commissariat of Education of June 20, 1918). The list of antiquities, objects of art and science to immediate return was not exhaustive, namely such items as "collections, paintings, historical documents, archives, church bells and utensils, antique furniture, etc." (p. 1).

It is noteworthy that this decree had striking differences from the decree of January 19, 1918, namely, it had an imperative character, namely, para. 4 imputed the duty to the local Soviet authorities to notify the commissariat for the affairs of Poland about the objects of antiquity, art and science known to them on the ground. For non-compliance with this rule, namely in cases of concealment, responsibility was taken from the popular at the time wording "in accordance with the severity of revolutionary laws" (paragraph 3). Considering these acts, it becomes possible to trace the tendency to strengthen of the state control, to increase responsibility, - as the initial steps toward the further establishment of total control in all spheres of people's life.

Also, during the period under review, attention was paid to the transfer of property evacuated from Lithuania to the jurisdiction of the Commissariat for Lithuanian Affairs. Namely, the Decree of the Council of People's Commissars No. 876 of 1918.11.19 "On State, public and private institutions, property, capital, etc." [21] evacuated and exported from the Lithuania" defined five types of institutions and property objects to transfer to the management of the Commissariat on Lithuanian Affairs at the People's Commissariat for the Affairs of Nationalities, among which, in Art. 1 were determined, inter alia, objects of art, as well as items of historical significance. Under the "management" the legislator understood "the right of supervision and control, which belongs exclusively to the Commissariat for Lithuanian Affairs".

In addition, the Commissariat for Lithuanian Affairs may be granted the right to actually dispose of this property. The order of transfer to the 
jurisdiction was defined in Art. 2 of this Decree. Art. 7 obligated all the People's Commissariats, local Soviet institutions and institutions subordinate to them to submit to the Commissariat for Lithuanian Affairs the necessary information and reports for the implementation of this activity.

Summing up the interim result, it should be noted that the three above-mentioned acts confirm the priority of international vector of the return of cultural property. Despite the unstable political and economic situation in the designated historical period, since the beginning of the establishment of socialist power in Russia there have been adopted legal acts aimed at addressing the issues of the turnover and protection of art and antiquities.

\section{Legal acts on Protection of Artworks and Antiquities in 1917-1922}

December 28, 1917, the Higher Council of National Economy in the import department of the RSFSR adopted a decree "On the Prohibition of the Importation of Luxury Goods" [22], according to which, from January 15,1918 , there were forbidden to be brought to Russia (from abroad across all borders, including including across the front and from Finland), all items indicated in the following articles of the Common Customs tariff for European trade 1906. And in paragraph 2 of this decree, it was established responsibility for a pass to Russia and for the smuggling of these items - a prison of up to two years and a fine before confiscating all property.

The most important role in the regulation of trade and the movement abroad of art and antiques played the Decree of the Council of People's Commissars No. 751 "On the prohibition of the export abroad of art and antiquities" [23] dated September 19, 1918. Its key aspects were expressed, firstly, in defining the purpose of prohibition the export of objects of special artistic and historical significance, namely, "the loss of the cultural treasures of the people"; secondly, it was developed the legal mechanism for obtaining permission for export abroad of art and antiquities from any place of the Republic. Namely, p.1 established the list of subjects authorized to issue this permission: 1) Board for Museums and the Protection of Monuments of Art and Antiquities in Petrograd and Moscow under the People's Commissariat of Enlightenment; 2) other bodies authorized by the Board; 3) The Commissariat for Foreign Trade (only after the preliminary conclusion and permission of the National Commissariat of Enlightenment). Provision 2 of this decree contained the obligation to register for shops, 
commission offices and individuals who trade in art and antiquities, or brokers for their trade, as well as individuals who make a paid assessment or examination of such items. Such registration was necessary to be made within three days after the publication of this decree in the Board for the Protection of Monuments of Art and Antiquities in Petrograd and Moscow under the People's Commissariat of Enlightenment or in bodies, by the Board authorized for this, and in the local bodies in the Divisions for People's Enlightenment under the Provincial Council Workers and Peasant Deputies. The regulatory act adopted in the explanation of the legal provisions of this decree gives grounds to assert that the list of subjects falling under the scope of this decree raised questions. Thus, in an explanation of the legal provisions prohibiting the export abroad of objects of art and antiquity designated in this resolution, on May 5, 1920, the decree of the Council of People's Commissars "On exporting musical instruments abroad" [24] was adopted, according to which the export of musical instruments abroad was allowed only by special permission of the People's Commissariat of Enlightenment on each instrument. The following regulatory documents in the field of turnover of art and antiquities was the Decree of the Council of People's Commissars No. 794 "On registration and preservation of monuments of art and antiquities owned by individuals, societies and institutions" [25] dated 1918.10.05. This act turns attention to itself by the fact that, according to this decree, the first state registration of all monumental and material monuments of art and antiquity was carried out in the Republic, both in the form of entire assemblies and individual objects, in whose possession they were (claim 1). Clause 2 provided for the registration of societies, institutions and individuals in possession of monuments, collections of art and antiquities, as well as individual items of great scientific, historical or artistic significance. Considering this act, a different, non-security, purpose of a post-revolutionary government comes to mind as the creation of a legal basis for further simplifying the nationalization process in the state (which later on actually happened). Records of these items also provided for the possibility of their forcible alienation or transfer to storage under the authority of state security agencies, provided "if they are safeguarded from danger of negligence of the owners or due to the inability of the owners to take the necessary measures of protection storage rules" (p.5). This confirms the thesis stated above about the dual nature 
of the goals of this decree - simplification of total control and obtaining information about the available private property of the population, legislatively fixing not only the process of state registration, but also the so-called "legal" conditions of expropriation. The fulfillment of all the functions of registration and recording of these items was assigned to the Commission for the Protection and Registration of Art and Antiquities. All owners of individual objects of art and antiquities (individuals, societies and institutions) were obliged to submit general information about the monuments of art and antiquities belonging to them no later than one month from the date of publication of this decree. The necessity of submitting the full list of such property to the Commission for the Protection and Registration in St. Petersburg and Moscow and in the provinces to the Provincial Councils of Workers 'and Peasants' Deputies, and to the Departments of Public Education was also consolidated; and in cases of impossibility for any reason to submit complete lists, notify the Commission accordingly. Owners of registered items or assemblies are assisted in their conservation and issued special security certificates (clause 4 ). The only reasonable point was paragraph 13, in which it was fixed that the effect of this decree did not apply to objects of art located at their authors.

In general, despite the fact that the main purpose of the decree was the protection of objects of art and antiquities, and, as indicated in the preamble, it was issued "for the preservation, study and the fullest possible acquaintance of the broad masses of the population with the treasures of art and antiquity" but according to our study, the provisions of the decree also played a big role in regulating the sphere of trade in these items, that is, obtaining economic benefits for the new government. Namely, clause 3 established the provision that "any alienation or transfer from one private or public domain to another, as well as the transfer, repair, amendment or alteration of registered monuments, collections and individual objects of art and antiquity cannot be produced without permission from the Board for Museums and the Protection of Art and Antiquities in St. Petersburg and Moscow." Based on the above mentioned, the conclusion is that the turnover of these items was taken into a firm regulatory framework by the state body, forming the normative basis for the further transition from socialism to communism, - i.e. complete abolition of private property. The Bolshevik's authorities took the first step towards the abolition of private property, by prohibiting the disposition of their property without the special permission. 
The next two years the government has ceased to pay attention to issues of antiques and works of art, concentrating on its predatory interests. Which was confirmed in the subsequent acts adopted in this sphere.

Among the latest acts of this historical period, it should be noted the normative act, the most important trade for antiques and antiquities - the Decree of the Council of People's Commissars of the RSFSR "On the Composition of the State Fund of Values for Foreign Trade" [26] of February 7, 1921. Firstly, its main goal was to compile a state reserve of artistic values and luxury goods and antiquities, which could serve as export items abroad, and thus regulate the aspect of international trade. Secondly, special bodies were created, namely, expert commissions; according to paragraph 1, the People's Commissariat for Foreign Trade was granted the right to form Expert Commissions acting on the basis of the Regulations approved by the People's Commissariat for Foreign Trade in agreement with the People's Commissariat of Education and the People's Commissariat of Finance. In paragraph 2 of the Decree, four tasks were assigned to the established Expert Commissions, such as 1) selection, 2) classification, 3) assessment and 4) registration of artistic and antiquarian-historical objects, luxury goods, which can serve for export. The Expert Commission consisted of representatives of the relevant departments of the People's Commissariat of Education (Main Committee for Museums and Fine Arts). All institutions and persons in charge of which were warehouses, shops, premises and in general any storage facilities, with the exception of the museums of the Republic and the storage facilities of the state museum fund, which are under the authority of the Main Committee on Museums Affairs, were allowed to freely provide representatives of the Commission to inspection, selection, registration of all things related to the subject of the Commission (p.4). A p. 5. granted the People's Commissariat of Foreign Trade the right to seize and store for the purposes of foreign trade the items selected by the Expert Commissions, thereby securing the legal basis for further expropriation of art and antiquities from the owners.

It is worth noting two decrees of 1921, in which the authorities no longer hide their political intentions to violate human rights and to abolish private property, as well as the expropriation of such objects, which was carried out in the order of requisitions and confiscations: the Decree of the Council of People's Commissars No. 37 "On requisitions and confiscations" [27] and 
the Decree of the Council of People's Commissars No. 564 "On the order of requisition and confiscation of property of individuals and societies" [28]. Analyzing the legislation in this area, one can come to the conclusion that such seizure could be committed by two bodies - the People's Commissariat of Education or Customs offices. The grounds for the requisition and confiscation of the People's Commissariat of Education under Art. 9 of the Decree of the Council of People's Commissars "On requisitions and confiscations" of January 3, 1921 became: "antiquities or art, exported abroad without permission, as well as those abandoned by the owner." The People's Commissariat of the Enlightenment exercised the right to requisition and confiscation of items directly or through local authorities. The exceptions were such subjects as (according to the notes to article 9): - subjects necessary for the professional activity of the teaching staff of higher and secondary educational institutions; - subjects necessary for state establishments performing scientific and practical tasks; - items of religious worship, although of historical or artistic importance (located in churches and prayer institutions of all confessions). As for the confiscation of items by the customs authorities, according to Art. 5 of the Decree of the Council of People's Commissars No. 564 "On the order of requisition and confiscation of property of individuals and societies" of October 17, 1921, confiscation by customs institutions was subject to "antiquities or art, exported abroad without the permission of the People's Commissariat of Education". These were the very last legal acts in this field before the creation of USSR in 1922.

\section{Conclusions}

The review of an exhaustive number of normative acts in the sphere of cultural heritage in 1917-1922 made it possible to determine the features characteristic of this period, the goals of the legislator and the mechanism for their implementation. There were identified notable features of this period, namely the short-term priority the return of cultural property to their historic homeland (international dimension), and turn the regulation, which from the one point suggests a balanced approach of the legislator with the expectation of further development of this sphere and from the other - creation of fundament for further expropriation.

Analyzing the legislative acts of post-revolutionary Russia, it becomes possible to identify two characteristic vectors in the field of legal securing 
of the protection and circulation of art and antiques. First, it is the legislative creation of a mechanism for registering and registering such items throughout the state (security function), and secondly, the normative consolidation of the need to return cultural values to their historical homeland (ethical function). It should be noted the interesting fact that the legislative consolidation of the return of foreign cultural values (namely, Polish, Lithuanian and Ukrainian works of art and antiquities), as well as the return of historical values of a religious nature, was carried out chronologically earlier than the creation of an all-Russian nationwide database. This fact indicates the importance of international cooperation in this field. At the same time, it can be considered not an ethical component or a real concern for the preservation of cultural values, as it may seem at first glance, but a purely political aspect. It can be assumed that the post-revolutionary government acted by "political coaxing".

It should also be noted that the period indicated in the article was characterized by the emergence and legislative consolidation of the complex (integrated) nature of measures in the field of cultural heritage protection.

In summary, there are highlighted the characteristics of the study period: 1) a legally enforceable importance of cultural heritage; 2) the consolidation of the ethical, not only material, values of art and antiquities at the legislative level; 3) the imperative nature of registration and recording of cultural values, 4) the multi-level nature and the principle of subsidiarity of the structure of bodies responsible for the protection and preservation of art and antiquities (at national and local levels). Unfortunately, the politics of that time was developed in a bad scenario, and as further history has shown, the "control" and "recording of items" - became the first step to their nationalization, and further denial of private property by the soviet government.

\section{References:}

1. Hoffman, B. (2005). Art and Cultural Heritage: Law, Policy, and Practice, Cambridge University Press, p. 600.

2. Council conclusions of 21 May 2014 on cultural heritage as a strategic resource for a sustainable Europe OJ C 183, 14.6.2014, p. 36.

3. Lerche, C.O. (1998, February). The Conflicts of Globalization. In International Journal of Peace Studies, vol. 3, p. 1, pp. 47-66.

4. Petkova, D. (2005). Cultural Identity in a Pluralistic World // Cultural Identity in an Intercultural Context. Edited by Diana Petkova, Jaakko Lehtonen. Jyväskylä: University of Jyväskylä, pp. 11-66. 
5. Fisman, R. \& Wei, S.-J. (2009). The Smuggling of Art, and the Art of Smuggling: Uncovering the Illicit Trade in Cultural Property and Antiques American Economic Journal: Applied Economics, American Economic Association, vol. 1(3), pp. 82-96.

6. Fisk, C.L. and Gordon, R.W. (2011). Forward: 'Law as...': Theory and Method in Legal History. UCI Law Review, vol. 1.3 (2011): pp. 519-541.

7. Jansen, M. (2005). War and Cultural Heritage: Cyprus after the 1974 Turkish Invasion, Minnesota Mediterranean and Eastern European Monographs XIV). Vol. 3, No. 2 (2015), pp. 128-140.

8. Alatalu, R. (2013). Estonia and international heritage protection, Estonian Cultural Heritage, Preservation and Conservation, I (2005-2012), pp. 156-158.

9. Prezelj, I. (2005). Smuggling as a threat to national and international security : Slovenia and the Balkan route. Series: Athena paper series; no. 5. 2005. Vol. 5, p. 1-100.

10. Petkova, D. (2005). Cultural Identity in a Pluralistic World // Cultural Identity in an Intercultural Context. Edited by Diana Petkova, Jaakko Lehtonen. Jyväskylä: University of Jyväskylä, pp. 11-66.

11. Weber, M. (2006). New Swiss Law on Cultural Property, International Journal on Cultural Property. Vol. 13(99), p. 113

12. Kunitz, M. (2001). Switzerland \& the International Trade in Art \& Antiquities. In: Northwestern Journal of International Law \& Business. Vol. 21. Issue 2. P. 519-542.

13. Renold Marc-André Jean (2010). Le droit de l'art et des biens culturels en Suisse : questions choisies, Revue de droit Suisse. Vol. 1, p. 137-220.

14. Amineddoleh, Leila Alexandra, The Protection of Abandoned Cultural Heritage in Spain, AEDON, Journal of Arts and Law Online, No. 3, 2012 (March 2012). Available at: http://ssrn.com/abstract $=2317395$

15. Lixinski, L. (2012). Luci e Ombre: The Bright and Dark Sides of international Heritage Law, 22 Italian Yearbook of International Law, pp. 133-153.

16. Amineddoleh L. (2013). The Role of Museums in the Trade of Black Market Cultural Heritage Property, Art Antiquity and Law, vol. XVIII, Issue 2, p. 28.

17. Postanovlenie Narodnogo Komisariata po Prosveshcheniyu RSFSR ot 1 dekabrya 1917 g. "O peredache trofeev Ukrainskomu narodu” Stat'ya № 76 Sobranie uzakoneniy $i$ rasporyazheniy pravitel'stva za 1917-1918. Upravlenie delami Sovnarkoma SSSR M. 1942, str. 62.

18. Coobshchenie Soveta Narodnykh Kommisarov O vydache kraevomu musul'manskomu s"ezdu «Svyashchennogo Korana Osmana» Stat'ya № 103 Sobranie uzakoneniy $i$ rasporyazheniy pravitel'stva za 1917-1918. Upravlenie delami Sovnarkoma SSSR M. 1942, str. 89.

19. Dekret SNK Stat'ya № 244, 1918.01.19 Ob okhrane i vozvrashchenie predmetov iskusstva i stariny prinadlezhashchikh pol'skomu narodu, Sobranie uzakoneniy $i$ rasporyazheniy pravitel'stva za 1917-1918. Upravlenie delami Sovnarkoma SSSR M. 1942, str. 270-271.

20. Postanovlenie Narodnogo Komissariata Prosveshcheniya, 1918.06.20 O vozvrashchenii pol'skomu trudovomu narodu evakuirovannogo iz Pol'shi 
kul'turnogo, khudozhestvennogo, nauchnogo i istoricheskogo dostoyaniya Sobranie uzakoneniy $i$ rasporyazheniy pravitel'stva za 1917-1918. Upravlenie delami Sovnarkoma SSSR M. 1942, str. 609 Stat'ya № 543.

21. Dekret Soveta Narodnykh Komissarov № 876 ot 1918.11.19 Ob evakuirovannykh i vyvezennykh iz predelov Litvy gosudarstvennykh, obshchestvennykh i chastnykh uchrezhdeniyakh, zavedeniyakh, imushchestvakh, kapitalakh i t. p. Stat'ya № 876. Sobranie uzakoneniy i rasporyazheniy pravitel'stva za 1917-1918. Upravlenie delami Sovnarkoma SSSR M. 1942, str. 1164-1166.

22. Postanovlenie Vysshego Soveta narodnogo khozyaystva po importnomu otdeleniyu RSFSR № 22128.12 .1917 «O zapreshchenii privoza predmetov roskoshi” Sobranie uzakoneniy i rasporyazheniy pravitel'stva za 1917-1918. Upravlenie delami Sovnarkoma SSSR M. 1942, str. 246.

23. Dekret Soveta Narodnykh Komissarov № 751 O zapreshchenii vyvoza za granitsu predmetov iskusstva i stariny ot 1918.09.19 Sobranie uzakoneniy $i$ rasporyazheniy pravitel'stva za 1917-1918. Upravlenie delami Sovnarkoma SSSR M. 1942, str. 960-961.

24. Dekret Soveta Narodnykh Komissarov Stat'ya № 174. O poryadke vyvoza zagranitsu muzykal'nykh instrumentov. Sobranie uzakoneniy i rasporyazheniy pravitel'stva za 1920 g. Upravlenie delami Sovnarkoma SSSR M. 1943. str. 263 1920.05.05.

25. Dekret Soveta Narodnykh Komissarov № 794. O Registratsii, prieme na uchet i okhranenii pamyatnikov iskusstva i stariny, nakhodyashchikhsya vo vladenii chastnykh lits, obshchestv i uchrezhdeniy. 1918.10 .05 g. Sobranie uzakoneniy $i$ rasporyazheniy pravitel'stva za 1917-1918 gg. Upravlenie delami Sovnarkoma SSSR M. 1942, str. 1008-1009.

26. Dekret Coveta Narodnykh Komissarov RSFSR "O sostavlenii gosudarstvennogo fonda tsennostey dlya vneshney torgovli" ot 7 fevralya 1921 g. Stat'ya № 69 Sobranie uzakoneniy i rasporyazheniy pravitel'stva za $1921 \mathrm{~g}$. Upravlenie delami Sovnarkoma SSSR M. 1944, str. 114.

27. Dekret Soveta Narodnykh Komissarov № 37. “O rekvizitsiyakh i konfiskatsiyakh" 3 yanvarya 1921 g. Sobranie uzakoneniy i rasporyazheniy pravitel'stva za 1921 g. Upravlenie delami Sovnarkoma SSSR M. 1944, str. 61-68

28. Dekret Soveta Narodnykh Komissarov № 564 "O poryadke rekvizitsii i konfiskatsii imushchestva chastnykh lits i obshchestv" 1921.10.17 Sobranie uzakoneniy i rasporyazheniy pravitel'stva za 1921 g. Upravlenie delami Sovnarkoma SSSR M. 1944, str. 915-918. 